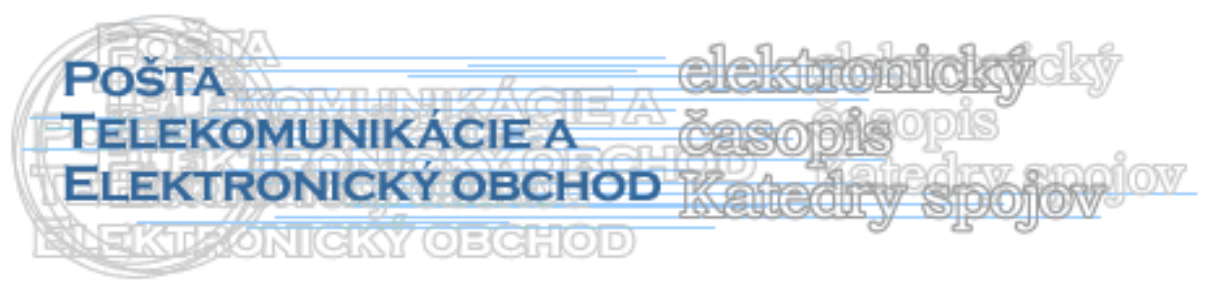

\title{
ŠIROKOPÁSMOVÝ PRÍSTUP V SLOVENSKEJ REPUBLIKE - POROVNANIE S KRAJINAMI EU
}

\author{
Juraj Fabuš*
}

Úvod

Séria článkov vzniká za účelom vysvetlenia a objasnenia pojmu širokopásmový prístup, hlavnou témou tohto článku je porovnanie stavu širokopásmového prístupu v Slovenskej republike s krajinami EÚ.

Zverejnenie práce je z dôvodu obšírnosti problematiky rozdelené do viacerých článkov, ktoré budú postupne publikované $\mathrm{v}$ tomto elektronickom časopise. V predchádzajúcich častiach boli vysvetlené základné pojmy z predmetnej oblasti, charakterizované jednotlivé služby, ako aj význam a výhody uplatnenia širokopásmového prístupu, nasledovat' bude porovnanie so stavom v krajinách V4, ako aj návrh opatrení, ktoré napomôžu k rozšíreniu využívania širokopásmového prístupu pre všetkých obyvatel'ov SR.

Ciel'om je zvýšit' povedomie o širokopásmovom prístupe, zvýšit' záujem o jeho využívanie, čo bude mat' konečný vplyv aj na postavenie Slovenska v rámci EÚ, kde sme medzi členskými krajinami na poslednom mieste vo využívaní širokopásmového prístupu. Články sú určené všetkým, ktorí širokopásmové služby už využívajú, ale aj pre tých, ktorí sa s nimi ešte len zoznamujú.

\section{Stav širokopásmového prístupu v krajinách EU}

Európska únia považuje za širokopásmový internet pripojenie s minimálnou rýchlost'ou $144 \mathrm{Kbps}$, ale pre nedostatok údajov nebol v žiadnej krajine započítaný počet zákazníkov mobilného $3 \mathrm{G}$ pripojenia.

Európska komisia pravidelne zverejňuje výsledky v oblasti širokopásmového prístupu jednotlivých členských krajín. V trinástej správe o pokroku voblasti jednotného trhu s telekomunikáciami uvádza, že až osem členských štátov EÚ predbehlo USA v nasadení širokopásmového pripojenia.

Hlavné body porovnávania širokopásmového prístupu EÚ sú:

- pokrytie oblastí s horšou dostupnost'ou širokopásmového pripojenia,

- podpora využívania širokopásmových komunikácií vo verejnom sektore,

- Širokopásmové pripojenie malých a stredných podnikov,

\footnotetext{
* Ing. Juraj Fabuš, PhD., Žilinská univerzita v Žiline, Fakulta prevádzky a ekonomiky dopravy a spojov, Katedra Spojov, Univerzitná 1, 01026 Žilina, Slovenská republika, tel.: +421 908171 890, E-mail: juraj.fabus@fpedas.uniza.sk
} 
- ̌rirokopásmové pripojenie verejných inštitúcií, škôl, knižníc, nemocníc a pod.,

- rôzne podporné aktivity, ako sú osvetové akcie, vzdelávanie, zvyšovanie počítačovej gramotnosti, projekty na monitorovanie stavu, a pod.

Svetovými lídrami v oblasti širokopásmového internetového pripojenia sú krajiny Dánsko, Fínsko, Holandsko a Švédsko, v ktorých miera dostupnosti tohto druhu pripojenia ku koncu roka 2007 presiahla 30\%. Spolu so Spojeným královstvom, Belgickom, Luxemburskom a Francúzskom mali uvedené krajiny EÚ v júli 2007 vyššiu mieru dostupnosti širokopásmového pripojenia ako USA, ktoré malo len $22,1 \%$.

Viditel'né rozdiely existujú $\mathrm{v}$ dostupnosti širokopásmového pripojenia medzi mestskými a vidieckymi oblast'ami, kde napr. DSL pokrytie vo vidieckych oblastiach dosahuje $71,3 \%$ v porovnaní s 89,3\% na vnútroštátnej úrovni (94\%-né pokrytie len v mestských oblastiach). V prípade káblového pokrytia je rozdiel zretel'nejší, lebo vo vidieckych oblastiach dosahuje iba $7,4 \%$ v porovnaní s $35,6 \%$ na vnútroštátnej úrovni. Rozdiel v pokrytí DSL a káblovom pokrytí medzi vidieckymi oblast'ami a vnútroštátnym priemerom je výrazný najmä na Slovensku, v Taliansku, Lotyšsku a Nemecku. (údaje k 31. decembru 2006).

Prostredníctvom reformných návrhov Komisie by sa malo umožnit' riešenie tejto problematiky ul'ahčením využívania tých častí frekvenčného spektra, ktoré sa uvol'nia prechodom na digitálne vysielanie, a ich ciel'om bude posilnit' možnost' širokopásmového pripojenia vo vidieckych oblastiach prostredníctvom bezdrôtových aplikácií.

Nasledujúci obrázok 1. popisuje mieru rozšírenia širokopásmového pripojenia vo svete (k 1. júlu 2007), pričom bolo vybraných 25 krajín sveta s najlepšími výsledkami.

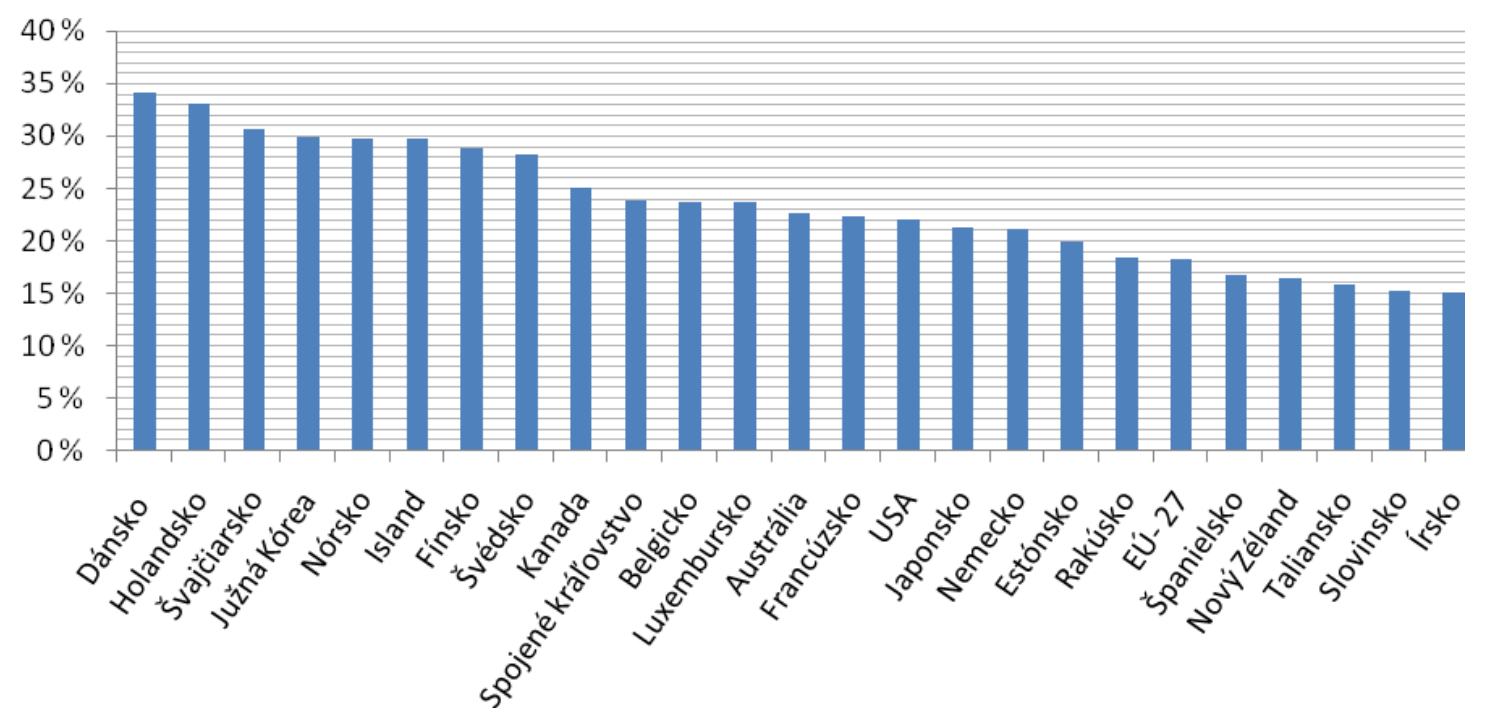

Obrázok 1. Miera rozšírenia širokopásmového pripojenia vo vybraných štátoch EÚ

Dostupné na: <http://www.google.sk/search?hl=sk\&q=S

pr\%C3\%A1 va+komisie+o+telekomunik\%C3\%A1ciach+2008\&btnG=H\%C4\%BEada \%C5\%A5 \&meta=>

Z obrázku vyplýva, že Európska únia ako celok, je ešte stále na chvoste v rozšírení širokopásmového pripojenia, na prvom mieste je Dánsko, posledné Írsko. Teda možno 
konštatovat', že štáty Európy sú v miere rozšírenia širokopásmového prístupu na poprednom mieste, ale v priemere EU zaostáva.

DSL je zatial' stále hlavnou technológiou širokopásmového pripojenia v rámci EÚ a predstavuje $80 \%$ všetkých pripojení. Rast práve v oblasti DSL pripojení bol však relatívny v porovnaní s ostatnými technológiami, pretože v roku 2007 dosiahol 22,4\% v porovnaní s 34,5\% v roku 2006. Zároveň sa zvyšuje potenciál na výrazné posilnenie hospodárskej sút’aže v rámci platformy prostredníctvom alternatívnych technológií, najmä káblového prístupu, siete káblov zo skleného vlákna, bezdrôtového prístupu a mobilných služieb.

Rast v oblasti káblového širokopásmového pripojenia dosahoval od januára 2007 podiel 21,7\%, výrazný bol v Nemecku, Pol'sku, Spojenom král'ovstve, Španielsku, Mad'arsku a Belgicku. Vo Švédsku, Litve a Estónsku, členských štátoch s najvyšším podielom pripojení prostredníctvom siete káblov zo skleného vlákna, sa v tejto oblasti zvýšil trhový podiel v porovnaní so situáciou na konci roku 2006. Bezdrôtové miestne vedenie predstavuje významný spôsob pripojenia v Českej republike, Írsku na Slovensku, kde sa v priebehu roku 2007 dosiahol výrazný nárast v tejto oblasti.

Dostupnost' širokopásmového pripojenia je obmedzená najmä v t’ažšie prístupných oblastiach, akými sú ostrovy a hornaté oblasti, ako aj vo vidieckych regiónoch, ked’že nízka úroveň dopytu mimo mestskej aglomerácie odradzuje poskytovatel'ov týchto služieb. Správa Európskej parlamentu pritom poukazuje na skutočnost', že vnútorný trh s takmer 500 miliónmi občanov využívajúcimi širokopásmové pripojenie by vytvoril "celosvetovo jedinečné množstvo používatel'ov", čo by umožnilo Európe stat' sa vo svete vedúcim poznatkovo založeným spoločenstvom.

\section{Slovensko a krajiny EU}

Slovenská republika si v roku 2007 v porovnaní s ostatnými európskymi krajinami pohoršila v rozšírení širokopásmového pripojenia k Internetu. K januáru 2008 klesla až na 25. miesto spomedzi všetkých 27 krajín Európskej únie. Celkovo bolo na Slovensku na začiatku roka 476666 fixných širokopásmových prípojok, z toho až viac ako 73 tisíc realizovaných bezdrôtovou technológiou, ktorá je momentálne vel'mi populárna

Slovensko malo k 1. januáru 2008 penetráciu 8,8\% na obyvatel’a, pričom bolo predbehnuté Gréckom $(9,1 \%)$ aj Rumunskom $(9,8 \%)$. Za Slovenskom sa nachádza už len Pol'sko $(8,4 \%)$ a Bulharsko $(7,6 \%) .[1]$

V rámci EÚ dosiahlo najvyšší rast Fínsko, Nemecko, Švédsko, Írsko a Cyprus. Zatial' čo v prípade štátov ako sú Fínsko a Švédsko je nárast logickým pokračovaním už pokročilého vývoja, pre d’alšie tri krajiny predstavuje nárast snahu dohnat' zameškané.

Pokrytie DSL na slovenskom vidieku dosahuje podl'a 29.5\%, rozdiel oproti celoštátnemu priemeru je až 36.2\%. V tomto ukazovateli je Slovensko štvrté najhoršie, vyšší rozdiel je len v Taliansku, na Cypre a na Malte. Počet bezdrôtových fixných pripojení, realizovaných zvyčajne pomocou technológií WiFi a Wimax, dosiahol 73834.

Správa uvádza počet optických prípojok do domu technológiou FTTH až 48250. Zvyšných 26234 širokopásmových prípojok pripadá na ostatné technológie, pripojenie LAN, satelitné pripojenie a pripojenie d'alšími technológiami. 
Pre lepšie znázornenie slúži nasledujúci obrázok 2. (stav k 19.3. 2008)

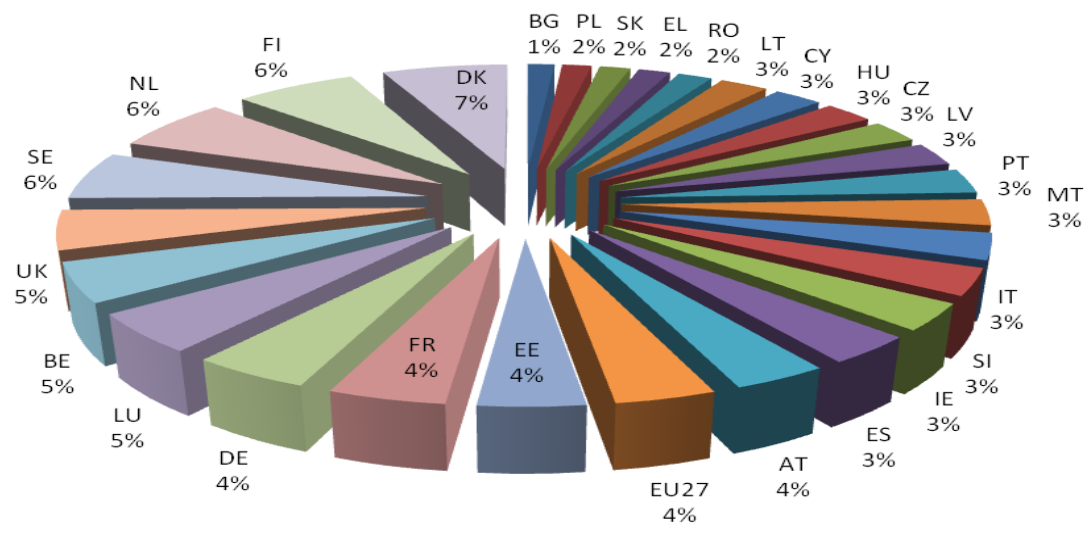

Obrázok 2. Miera rozšírenia širokopásmového pripojenia v EÚ

Dostupné na: <http://ec.europa.eu/information_society/policy/ecomm/doc/ library/annualreports/13th/com_2008_153_sk_final.pdf

Počet účastníckych vedení s pevným širokopásmovým pripojením prekročil 1.januáru 200899 miliónov v porovnaní s 80 miliónmi v januári 2007. Rozdiel medzi najvyššou a najnižšou mierou rozšírenia sa v členských štátoch zvýšil z 27,4\% v januári 2007 na 28\% v januári 2008.

Telekomunikačný úrad SR (TÚ SR) na začiatku roka 2008 informoval verejnost', že zaslal Európskej komisii podklady, z ktorých vychádza penetrácia širokopásmového prístupu bez ohl'adu na použité technológie (a bez ohl'adu na možnost' použitia rôznych metodík) na úrovni 17,24 percenta. Toto číslo sa podstatne priblížilo úrovni priemeru krajín EÚ, ktorý je 20 percent. Európska komisia zverejnila správu, podl'a ktorej penetrácia na Slovensku dosiahla úroveň 8,8 percenta. Vznikol tak priestor na kritiku Slovenska a regulátora trhu.[1]

Európska komisia napríklad do penetrácie nezapočítava technológie mobilných operátorov, aj ked' rýchlost'ou i d'alšími parametrami spĺnajú požiadavky definície širokopásmového prístupu. Práve tieto technológie predstavujú zaujímavý podiel na úrovni penetrácie.

Problémom je aj fakt, že členské štáty EÚ nepredkladajú vstupné údaje podl'a jednotnej metodiky. Slovensko napríklad predkladá podl'a požiadavky počet prístupových miest Wi-Fi sietí, ktoré sú na Slovensku vel'mi rozšírené, ale niektoré krajiny uvádzajú počet používatel’ov týchto sietí. Takto vzniká vel'ký rozdiel vo vstupných údajoch členských krajín.

Prenajatými okruhmi je realizovaných 972 prípojok širokopásmového internetu, len 4 sú realizované cez satelit. Na ostatné typy pripojenia pripadá 21024 prípojok, nie je ale známe aké technológie prevažujú v tejto skupine. Okrem toho je na Slovensku okolo 500 verejných WiFi hotspotov.[2] 
Nasledujúci obrázok 3 zobrazuje stav krajín EÚ v počte DSL liniek.

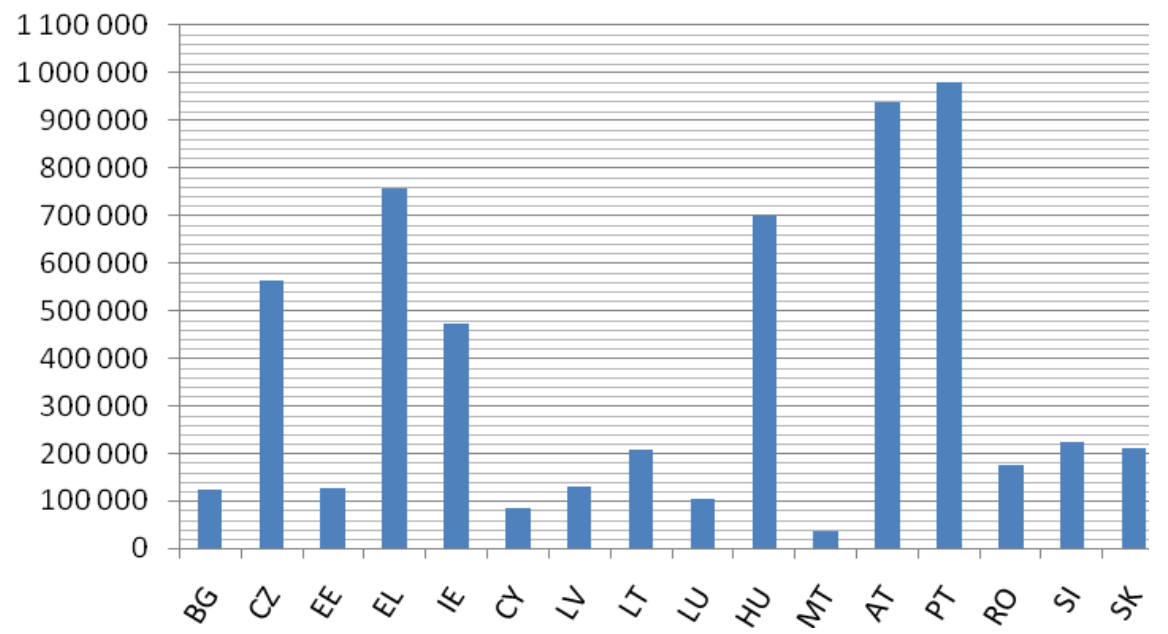

Obrázok 3. Porovnanie vybraných krajín EÚ v počte DSL liniek

Dostupné na: <ec.europa.eu/.../ecomm/ doc/ implementation_enforce ment/broadband_access/Broadband_data_july07_final.pdf>

Európska únia musí zvýšit' svoje úsilie pri podpore využívania širokopásmových služieb a stimulovat' d’alší rozvoj, najmä v menej rozvinutých oblastiach Európskej únie. Taktiež aj členské štáty musia aktualizovat' svoje národné stratégie pre vysokorýchlostný prístup, lebo práve ich dokumenty môžu stanovovat' ciele týkajúce sa pokrytia a využívania na základe aktívneho partnerstva s regionálnymi orgánmi a s využitím súčinnosti medzi alternatívnymi zdrojmi financovania (vnútroštátne zdroje, štrukturálne fondy, a iné). Národné stratégie pre vysokorýchlostný prístup by mali rovnako stanovit' jasné ciele ohl'adom pripojenia škôl, orgánov verejnej správy a zdravotných stredísk.

Z obrázku 4 vyplýva, že najlepšie je na tom z EÚ Island, naopak najhoršie Grécko. Slovensko sa nachádza opät' na chvoste.

Internetová penetrácia je na Slovensku oproti krajinám EÚ stále nízka, v porovnaní napr. so škandinávskymi krajinami ako sú Švédsko, Fínsko, Dánsko, ktoré sú lídrami EÚ, ale tiež v porovnaní s niektorými novými členmi, predovšetkým pobaltskými krajinami ako napr. Estónsko. Slovensko zaostáva nielen v úrovni, ale aj v dynamike rozvoja IS.

Aj medzi jednotlivými členskými krajinami možno identifikovat' značné rozdiely. Napríklad v nových členských krajinách je počet použivatel'ov tohto pripojenia d'aleko nižší ako v tých ostatných. Môže za to nedostatočne rozvinutá telekomunikačná infraštruktúra a z toho vyplývajúce vysoké ceny, ktoré robia zo služby skôr luxusný tovar ako prostriedok dennej spotreby. 
Obrázok 4 zobrazuje podiel širokopásmového prístupu v krajinách EÚ (stav k 3. 12. 2007).

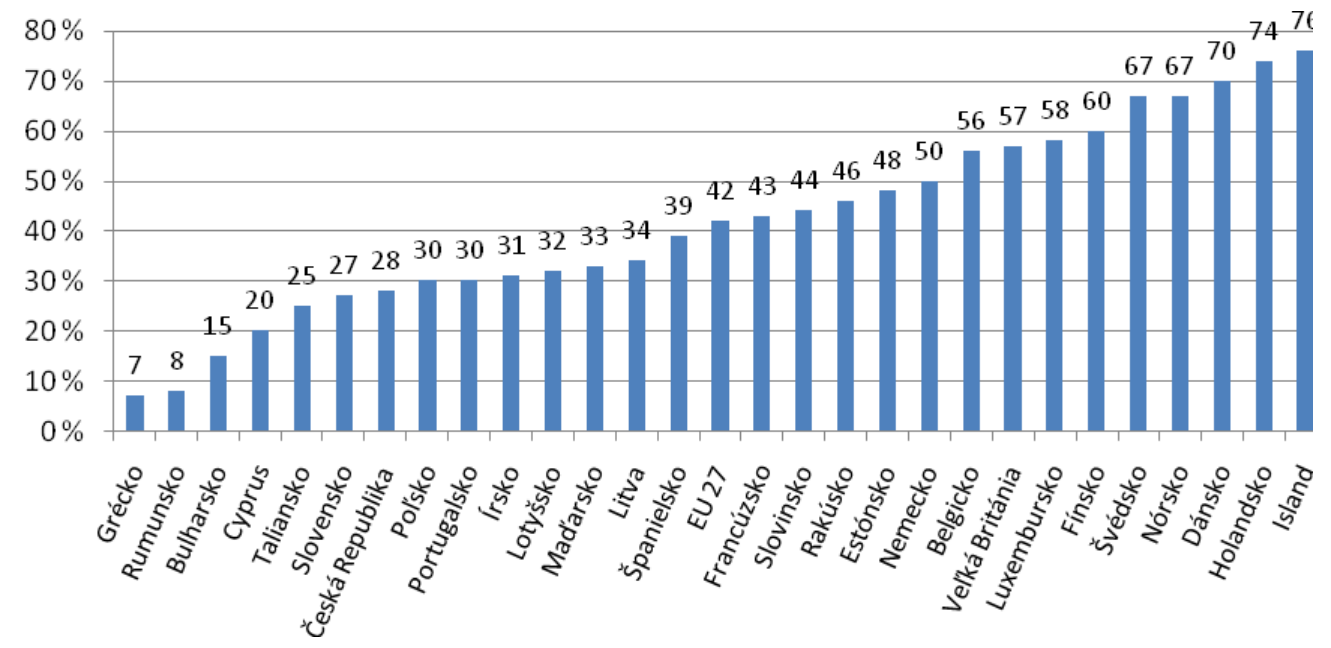

Obrázok 4. Podiel širokopásmového prístupu v krajinách EÚ v \%

Dostupné na:

<http://epp.eurostat.ec.europa.eu/pls/portal/docs/PAGE/PGP_PRD_CAT_PREREL/PGE_CAT_PREREL_YEA

R_2007/PGE_CAT_PREREL_YEAR_2007_MONTH_12/4-03122007-EN-BP.PDF>

Na chvoste EÚ sa nachádzajú Slovensko, Pol'sko, Bulharsko, Rumunsko a Grécko. Vo všetkých spomenutých krajinách využíva širokopásmové pripojenie menej ako 7\% populácie, na druhej strane, európskymi lídrami v tomto smere sú Holandsko $(33,1 \%)$ a Dánsko $(37,2 \%)$. Absolútnym svetovým lídrom v budovaní IT infraštruktúry je Južná Kórea, ktorá má zároveň najväčšie pokrytie populácie širokopásmovým pripojením na internet.

\section{Záver}

Odvetvie telekomunikácií je najväčšou jednotlivou súčast'ou odvetvia informačných a komunikačných technológií (IKT) a predstavuje takmer 44\% jeho celkovej hodnoty. Výška príjmov v roku 2007 sa odhaduje na 293 miliárd EUR v porovnaní s 289 miliardami EUR v roku 2006. Z hl'adiska príjmov klesá využívanie pevných hlasových telefonických služieb, zatial' čo v súvislosti s mobilnými službami a pevným širokopásmovým pripojením je možné pozorovat’ neustály rast.

Zo štatistík vyplýva, že aj ked' penetrácia broadbandu v SR akceleruje, jej rast je stále podpriemerný a dvojnásobne to platí o úrovni penetrácie. Spolu s Gréckom a Pol'skom sme stále outsidermi v rámci EÚ. Nepríjemným zistením je podpriemerný rast penetrácie rýchleho internetu na Slovensku, vd’aka jeho nízkemu rozšíreniu, tzn. vysokému podielu nepripojených domácností. Prevažná väčšina členských štátov zvyšuje svoj podiel obyvatel'stva vybavených broadbandom výrazne rýchlejšie a na pohl'ad paradoxom je, že najrýchlejšie rastie penetrácia $\mathrm{v}$ krajinách $\mathrm{z}$ tohto pohl'adu nadpriemerných. 


\section{Literatúra}

[1] Lídrami v rýchlom pripojení na internet sú európske krajiny. Dostupné na: <http://www.itas.sk/buxus/generate_page.php?page_id=1342>

[2] SR v broadbande na chvoste EÚ, WiFi a Wimax prípojok viac ako 73 tisíc Dostupné na: <http://www.dsl.sk/article. php?article $=5461 \&$ title $=>$

[3] Stratégia informatizácie spoločnosti v podmienkach SR a Akčný plán. Dostupné na: <http://www.elet.sk/brt/ egovernment/ vlastnymat.rtf>

[4] ŽILÁKOVÁ, D., Využitie štrukturálnych fondov EÚ a Informačná spoločnost'. Dostupné na: <www.p3.sk/domain/flox/files/download/Prezentacia_Denisa_SF_Technopol.ppt>

[5] Národná stratégia pre širokopásmový prístup. 2005. Dostupné na: < http://www.telecom.gov.sk/index/index.php?ids=3891>

\section{Grantová podpora}

Článok je súčast’ou riešenia úlohy Zvýšenie atraktívnosti vysokej školy prostredníctvom marketingovej komunikácie vzdelávacej inštitúcie - KEGA 3/5030/07. 